\title{
COMPARISON BETWEEN THE CHARACTERISTICS OF WIND POWER CALCULATION AND SOLAR RADIATION AT ONNE
}

\author{
L. E. AKPABIO, A. B. UDOIMUK, S. E. ETUK, I. ESSIEN AND N. E. ITUEN \\ (Received 5, April 2006; Revision Accepted 25, February 2007)
}

ABSTRACT

Data on wind speed and global solar radiation over the period 1985 - 1999 for Onne obtained from the International Institute of Tropical Agriculture (IITA) stationed at Onne, Nigeria have been compiled and evaluated, to determine the wind power which is compared with the global solar radiation energies. Monthly and annual data for global solar radiation energies measured at the station were determined. The monthly average solar radiation energies range from $2777.80 \mathrm{Wm}^{-2}$ to $4163.92 \mathrm{Wm}^{-2}$ with an overall average as $3465.58 \mathrm{Wm}^{-2}$. The derived monthly and annual average wind speeds range from $0.84 \mathrm{~ms}^{-1}$ to $1.09 \mathrm{~ms}^{-1}$ and from $0.64 \mathrm{~ms}^{-1}$ to $1.28 \mathrm{~ms}^{-1}$. respectively. The monthly available wind power density and maximum extractable wind power range from 0.33 $\mathrm{Wm}^{-2}$ to $1.40 \mathrm{Wm}^{-2}$ and $0.20 \mathrm{Wm}^{-2}$ to $1.10 \mathrm{Wm}^{-2}$, respectively.

KEYWORDS: Characteristics, wind power, solar radiation.

\section{INTRODUCTION}

Nigeria has abundant reserves of the major fossil fuels, as well as renewable energy resources like solar energy, biomass resource, hydropower and wind energy (Akapbio 1992. Akpabio et al 1999, Akpabio and Udoimuk 2003, Akpabio et a 2003. Akpabio et al 2004 and Akpabio et al 2005). One of the most important demands of energy in every society is that it is needed for the cooking of food. In most of the developing countries like Nigeria, cooking takes a very large part of the total energy.

For example in South-South of Nigeria, $80 \%$ of the total energy goes into cooking and most of this energy comes from firewood. The people living in rural areas purchase a few percentage of the firewood required for their cooking needs and the rest is got from cutting trees in the forest or in the residential areas causing soil erosion. Plants, as well as producing all the food for both the human beings and their animals, keep the oxygen supply of the earth constant.

A large percentage of the people live in the rural areas in most developing countries and especially in Nigeria, and often in such remote locations they are not accessible to the national grid. The absence of electricity and other social amenities in these areas has brought about migration of the youth from rural to urban centers in search of jobs and good things of life This paper presents the comparison of solar and wind energy with their possible utilization in Onne and its environ.

\section{MATERIALS AND METHOD}

Global solar radiation and sunshine duration during the period 1984 to 1999 were supplied by IITA (International Institute for Tropical Agriculture) station at Onne, high rainfall station located at latitude $4^{\circ} 46^{\prime} \mathrm{N}$. longitude $7^{\circ} 10^{\prime} \mathrm{E}$ with an altitude of $10 \mathrm{~m}$. The same data has been used by Akpabio and Etuk 2003 to develop a Page - type formular for Onne as:

$$
H / H_{0}^{\circ}=0.23+0.38\left(S / S_{0}\right)
$$

Where $H, H_{0}, S$ and $S_{0}$ are the monthly average daily global solar radiation, monthly average daily extraterrestrial radiation, monthly average daily number hours of bright sunshine and monthly average day length in hours respectively. Wind speed data, for the period (1985-1999) was also supplied by the same station. Wind speed measurements fluctuate in random manner with respect to time, height above ground and terrain roughness. The reference wind speed is therefore generally related to a height of $10 \mathrm{~m}$ above ground level in flat and open terrain. Since wind data supplied by IITA were measured from a height of $2 \mathrm{~m}$ above ground level, it is therefore necessary to adjust the wind data to a height of $10 \mathrm{~m}$ in order to make it directly related to the objectives of people working in the renewable energy sector The correction is done using the power law (Musgrove (1987), Wolde-Ghiorgis (1988), Akpabio et. Al (1999).

$$
V_{1} N_{2}=\left(H_{1} / H_{2}\right)^{a}
$$

Where $V_{2}$ is the mean wind speed at height $\mathrm{H}_{2}$ meters recorded at the station, $V_{1}$ is the wind speed at height $H_{1} H_{2}$ is the anemometer height at the station and $H$, is the anemometer height at $10 \mathrm{~m}$. The magnitude of the exponent, $\alpha$, is given by (Qashou et al, 1986).

$a=\left(0.37-0.008 \ln V_{2}\right) /\left(1-0.088 \ln \left(H_{2} / H_{1}\right)\right)$

a depends on the roughness of the terrain. tıme of the day, the wind stability and wind speed level It varies from 0.1 to 0.4 for different stations (Musgrove (1987), Qashou et al (1986) and Rizk (1987). Since site selection plays an important role in the installation of wind energy systems, then the estimate of the wind energy at the projected site must be made (Anyanwu and Iwuagwu (1995), Lewis (1988), Gopalakrish and Sankar (1987). Akpabio et al Accepted for publication in JAS, Qashou et al (1986), Rizk (1987). Wolde-Ghiorgis (1988). Ramachandra et al (1997) and Persand et al (1999))

\section{SOLAR ENERGY AND WIND POWER ESTIMATION}

Solar energy value was measured by IITA station at Onne for the duration under consideration Wind power estimation is carried out as follows: for any wind stream with speed, $V(\mathrm{~m} / \mathrm{s})$, passing through an area, $A\left(\mathrm{~m}^{2}\right)$ the theoretical power, $P_{1}$, that is available can be obtained from Putnam (1948) and Considine (1977) as

$$
P_{1}=1 / 2 \rho A V^{3}
$$

Where $\rho$, the average air density at the location is given as $1.22 \mathrm{Kg} / \mathrm{m}^{3}$.

However, the maximum wind nower $P_{m}$ which can be extracted by an ideal wind turbine is presented by Goldine

L. E. Akpabio, Department of Physics, University of Uyo, P. M. B. 1017 Uyo. Akwa Ibom State, Nigeria

A. B. Udolmuk, Department of Physics, University of Calabar, Calabar, Nigeria

S. E. Etuk, Department of Physics, University of Uyo, P. M. B. 1017 Uyo. Akwa Ibom State Nigeria

I. Essien, Department of Physics, University of Uyo, P. M B. 1017 Uyo, Akwa Ibom State, Nigeria

N. E. Ituen. Department of Phvsics. Universitv of Uvo. P. M. B 1017 Uvo. Akwa Ibom State. Niqeria 
(1955) as:

$$
P_{m}=(0.593) / 2 \rho A V^{3}
$$

Which is $59.3 \%$ of the theoretical wind power. Above expression for wind energy estimation has just been employed. by Akpabio et al (2005) in their article submitted to Journal of Nigerian Environment Society.

\section{RESULTS AND DISCUSSION}

An inspection of Table 1 which represents the wind speed (from 1985 to 1999) shows that;, the yearly mean wind speed varies between $0.64 \mathrm{~ms}^{-1}$ and $1.28 \mathrm{~ms}^{-1}$ with an overall mean of $1.26 \mathrm{~ms}^{-1}$. The highest wind speed of $1.80 \mathrm{~ms}^{-1}$ was recorded in March 1985 and highest monthly mean value of $1.09 \mathrm{~ms}^{-1}$ also occurred in this month. While monthly mean - wind speed, vary between $0.84 \mathrm{~ms}^{-1}$ and $1.09 \mathrm{~ms}^{-1}$. The monthly mean available wind power density varies between $0.33 \mathrm{Wm}^{-2}$ corresponding to $2.89 \mathrm{kWhm}^{-2}$ and $1.40 \mathrm{Wm}^{-2}$ corresponding to $12.26 \mathrm{KWhm}^{-2}$. While the monthly mean maximum extractabie wind power by any Wind Energy Conversion System (WECS) varies between $0.20 \mathrm{Wm}^{-2}$ corresponding to $1.75 \mathrm{KWhm}^{-2}$ and $1.10 \mathrm{Wm}^{-2}$ corresponding to $9.64 \mathrm{kWhm}^{-2}$.

Table 1: Estimated Wind speed (m/s) for Onne

\begin{tabular}{|l|l|l|l|l|l|l|l|l|l|l|l|l|l|}
\hline Year & J & F & M & A & M & J & J & A & S & O & N & D & $\begin{array}{l}\text { Yearly } \\
\text { Mean }\end{array}$ \\
\hline 1985 & 1.33 & 1.42 & 1.80 & 1.40 & 1.60 & 1.45 & 1.03 & 1.16 & 1.33 & 1.06 & 0.90 & 096 & 1.28 \\
\hline 1986 & - & 1.33 & 1.42 & 1.60 & 1.45 & 1.36 & 1.35 & 1.54 & 1.70 & - & - & - & 0.97 \\
\hline 1987 & - & 1.24 & - & 1.96 & 1.11 & 1.03 & 0.90 & 1.11 & 0.94 & 0.55 & 0.30 & - & 0.64 \\
\hline 1988 & 0.32 & 0.63 & 0.72 & 1.50 & 1.57 & 1.37 & 1.34 & 1.40 & 1.31 & 1.10 & 0.90 & 0.87 & 1.08 \\
\hline 1989 & - & - & 1.50 & 1.42 & 1.12 & 1.53 & 1.40 & 1.40 & 1.33 & 1.14 & 1.00 & 0.85 & 1.06 \\
\hline 1990 & 1.10 & 1.30 & 1.52 & 1.58 & 1.45 & 0.96 & 0.63 & 1.40 & 1.14 & 1.01 & 0.94 & 0.96 & 1.16 \\
\hline 1991 & 0.98 & 0.87 & 1.04 & 1.00 & 1.26 & 1.40 & 1.44 & 1.46 & 1.14 & 0.97 & 0.77 & 1.01 & 1.11 \\
\hline 1992 & 0.25 & 1.24 & 1.24 & 1.18 & 1.18 & 1.09 & 1.04 & 1.11 & 1.20 & 1.04 & 0.75 & 0.76 & 1.00 \\
\hline 1993 & 0.05 & 1.24 & 1.18 & 1.06 & 1.04 & 0.94 & 0.94 & 1.01 & 0.94 & 0.90 & 0.84 & 0.63 & 0.98 \\
\hline 1994 & $\mathbf{0 . 9 1}$ & 1.15 & 1.12 & 1.11 & 1.00 & 1.01 & 0.91 & 1.05 & 1.01 & 0.97 & 0.77 & 0.74 & 0.93 \\
\hline 1995 & 1.24 & 1.50 & 1.12 & 1.46 & 1.40 & 1.33 & 1.14 & 0.90 & 0.87 & 0.61 & 0.96 & 0.90 & 1.12 \\
\hline 1996 & 0.87 & 1.12 & 0.97 & 0.88 & 0.97 & 0.75 & 0.79 & 0.27 & 1.33 & 1.04 & 0.88 & 0.97 & 0.90 \\
\hline 1997 & 0.89 & 0.99 & 1.29 & 1.25 & 1.07 & 1.13 & 1.34 & 1.32 & 1.19 & 1.11 & 0.78 & 0.71 & 1.08 \\
\hline 1998 & 0.91 & 1.04 & 1.09 & 1.29 & 1.26 & 1.00 & 1.17 & 1.40 & 1.06 & 0.97 & 0.78 & 0.55 & 1.05 \\
\hline 1999 & 0.88 & 1.04 & 1.24 & 1.08 & 1.99 & 0.98 & 1.06 & 1.26 & 1.26 & 1.11 & 0.56 & 0.83 & 1.03 \\
\hline Mean & 0.86 & 1.03 & 1.09 & 1.09 & 1.00 & 0.94 & 0.98 & 1.06 & 1.04 & 0.84 & 0.72 & 0.68 & \\
\hline
\end{tabular}

For power demands above $10 \mathrm{KW}$, it is usual to retain the diesel engine (for industrial or communal purposes), which provides the certainty of power on demand; the main usefulness of the wind turbine will be to save diesel fuel and to reduce the overall cost of energy delivered. At lower power levels' (leses than ' $10 \mathrm{KW}$ ) as what is obtained at Onne, wind turbines with battery storage may replace diesel engines. Such wind/battery systems could be used in a wide range of applications such as lightning, radio and television receivers and in communication.
From Table 2, we have the values of global solar energy as obtained from Akpabio and Etuk (2003). The annual mean solar energies measured at Onne lies between $2777.80 \mathrm{Wm}^{-2}$ corresponding to $10.00 \mathrm{MJm}^{-2} \mathrm{~h}^{-1}$ and $4163.92 \mathrm{Wm}^{-2}$ corresponding to $1499 \mathrm{MJm}^{-2} \mathrm{~h}^{-1}$ with an overall average of $3455.58 \mathrm{Wm}^{-2}$ corresponding to $12.44 \mathrm{MJm}^{-2} \mathrm{~h}^{-1}$. To illustrate the variety in shape and range of the monthly mean wind and solar energy, the corresponding data for the location are shown in Figures 1 and 2. 

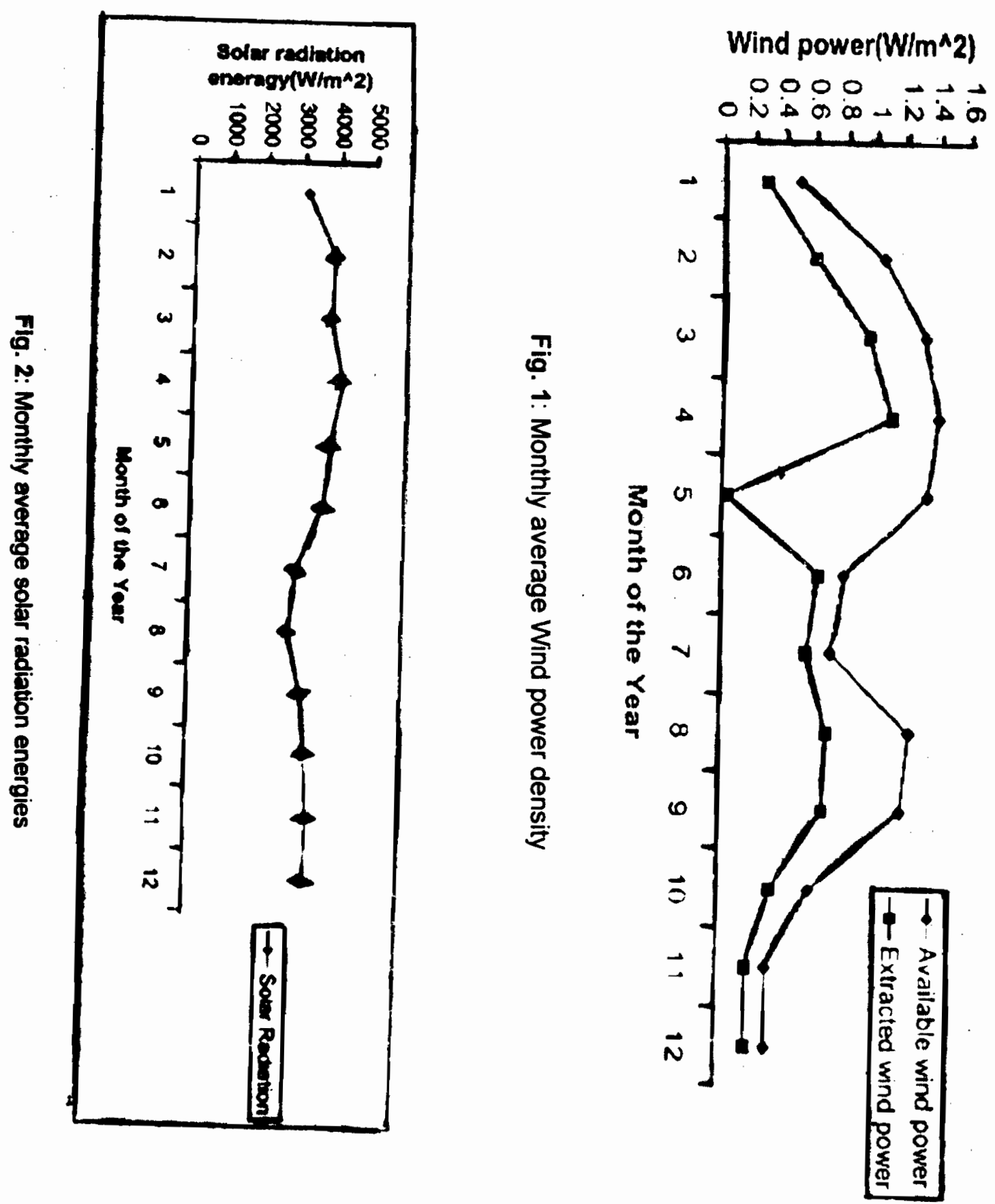

As observed from the figures. the monthly mean power pattern tends to be higher during the periods February - April, but wind power is relatively small when compared with solar energy. Hence, the power pattern is lower during the rainy (November to April). From these results wind energy is quit attractive for water pumping, for the provision of electricity for communal television viewing, refrigeration of drugs and for season (May to October) than that of the dry season

Table 2: Monthly average measured values of $H$ for Onne during $1984-1999$ (Akpabio and Etuk, 2003)

\begin{tabular}{|c|c|c|c|c|c|c|c|c|c|c|c|}
\hline \multicolumn{12}{|c|}{ Months } \\
\hline Jan. & Feb. & Mar. & Apr. & May & Jun. & Jul. & Aug & Sep & $\mathrm{OCl}$ & Nov. & Dec. \\
\hline $\begin{array}{l}H\left(W / m^{2}\right) \\
3119.49\end{array}$ & 3916.70 & 3797.25 & 416392 & 3838.92 & 3677.81 & 2961.13 & 277780 & 315558 & 3302.80 & 3408.36 & 3355.58 \\
\hline
\end{tabular}


CONCLUSION

The meteorological parameters (such as global solar radiation, sunshine duration and wind speed data) reported in this paper are mainly intended to verify the climatic conditions likely to affect the operation of solar and wind systems that may be set up at a later date. Most solar and wind energy technologies do require the means and variances of solar radiation and wind speed for design purposes. Summing up the findings, it can be concluded that wind power at Onne is relatively small (but not completely absent) when in comparison with solar energy. This station (Onne) may be poorly observed and it is not located in the windiest environment. Widespread of wind measuring devices located at suitable places would provide more reliable wind power estimation. Cases of roof being blown-off and permanently deformed trees along coastal line in this region indicate that there might exist higher wind speeds than those measured by the nearest meteorological stations. The immediate application of wind power is in water pumping, lighting, and radio and television receivers as well as in communication.

Onne, which is IITA high rainfall station, still has an excellent annual mean solar insolation of $3.5 \mathrm{KWhm}^{-2} \mathrm{day}^{-1}$ as what is obtained over Europe or U.S.A (Qashou et al (1986)). Solar energy applications lies on drying of agricultural products and solar distillation units. The data presented in this paper can be considered as the nucleus information for executing research and development of solar and wind energy projects. Finally, several automatic weather stations that record data on a temporal and spatial basis will be needed. These stations will be considered as complementary to the existing stations and will serve as a good source of information for wind and solar energy exploitation in Onne.

\section{ACKNOWLEDGEMENT}

The authors are grateful to the IITA (International Institute of Tropical Agriculture) station at Onne for providing the data. They also appreciate the financial support of LASE Radiation/Radon group for this project.

\section{REFERENCES}

Akpabio, L. E. 1992. Comparison between solar radiation energy and the characteristic of wind power calculations in south-eastern Nigeria. Nigeria Journal of Physics: $4: 15-20$.

Akpabio, L. E., Eno, E. E., Ekpe, S. D and Etuk, S. E., 1999. The available wind energy characteristic in (a Nigeria environment) Uyo, Nigeria. Integrated Journal of Sciences and Engineering: 2: $73-80$

Akpabio, L. E., Udoimuk, A. B. and Essiett, A. A. Wind Energy potential in Eastern Nigeria. Accepted for publication in JAS.

Akpabio, L. E. and Etuk, S. E. 2003. Relationship between Global Solar Radiation and Sunshine Duration for Onne. Nigeria. Turk. J. of Physics: 27: $161-167$

Akpabio, L. E. and Udoimuk, A. B. 2003. Characteristic Distribution of Total. Diffuse and Direct Solar
Radiation at Calabar. Global J. of Pure \& Applied, 9 : $139-145$

Akpabio, L. E., Ukpong, U. A. and Etuk, S. E. 2003. Analysis of Solar Radiation at Uyo, Nigeria. JAS. 6: 3607 - 3613

Akpabio, L. E., Udo, S. O. and Etuk, S. E. 2004. Empirical Correlations of Global Solar Radiation with Meteorological data for Onne, Nigeria. Turk. J. Physics. 28: $205-212$.

Akpabio, L. E., Udo, S. O. and Etuk, S. E. 2004. Modeling global solar radiation for a tropical location: Onne, Nigeria. Turk. J. Physics. 29: 63-68.

Anyanwu, E. E. and Iwuagwu, C. J. 1995. Wind Characteristic and Energy potential for Owerri, Nigeria. Renewable Energy: 6: $125-128$.

Akpabio, L. E., Udoimuk, A. B., Sunday, E. and Ukut, Esther G., 2005 Preliminary study of wind Energy potential at Onne. Submitted for publication in the Journal of Nigerian Environmental Society (2005)

Considine, D. M., 1977 Energy Technology Handbook. McGraw-Hill, N. Y. pp. 68

Golding. E. W. 1955. The generation of Electricity by wind power.. Philosophical Library. N. Y. pp.72.

Gopalakrish, R. and Kumar, G. Sankar, 1987. Wind energy potential in the State of West Bengal, Solar and Wind Technology: 4: 405-406.

Musgrove, P. J. 1987. Wind Energy Conversion: Recent Progress and Future prospects. Solar and Wind Technology, 4: $37-40$.

Lewis, G. 1986. Wind power availability in Zimbabwe. Solar and Wind Technology: 3: 73-74

Persand, Shashi, Flynn, Damian and Fox, Brendan, 1999. Potential for wind generation on the Guyana Coastlands. Renewable Energy: 18: 175-189.

Putnam, P. C., 1948. Power from the wind. Van Nostrand, N. Y. pp. 68.

Qashou, M., El-Mulki, H., Jaradat, A. and Ta'ani, R., 1986. Compilation and evaluation of solar and wind energy resources in Jordan. Solar and Wind Technology: 3 : $293-304$

Ramachandra, T. V., Subramanian, D K. and loshi, N. V., 1997. Wind energy potential assessment in Uttrara Kannada district of Karnataka, India. Renewable Energy: 10(4): $585-611$

Rizk, M. 1987. Wind characteristic and the available wind energy in Egypt Solar and Wind Technology. 4?(4): $491-499$.

Woide-Ghiorgis. W. 1988 Wind energy survey in Ethiopia. Solar and Wind Technology 5(4) : $341-351$ 